\title{
ANALISIS KEPUASAN PELANGGAN TERHADAP APLIKASI PELAYANAN PELANGGAN DENGAN METODE CSI DAN SERVQUAL
}

\author{
Andreas Adi Trinoto ${ }^{1}$, Ahmad Zamakhsari ${ }^{2}$ \\ Program Studi Teknik Informatika, Universitas Indraprasta PGRI ${ }^{1}$ \\ Praktisi Pelayanan Pelanggan ${ }^{2}$ \\ a.trinoto@gmail.com ${ }^{1}$,ahmad.zamakhsari@gmail.com²
}

Submitted March 3, 2021; Revised March 3, 2021; Accepted April 4, 2021

\begin{abstract}
Abstrak
Kereta Api Indonesia (KAI) sebagai salah satu perusahaan milik negara yang menyediakan jasa kepada masyarakat dirasakan bagus beberapa tahun kebelakang dan menjadi tujuan peneliti melakukan survey kepuasan pelanggan terhadap aplikasi pelayanan pelanggan Genesys salah satu produk Microsoft yang sudah terhubung dengan media sosial sebagai aplikasi pendukung dalam melayani pengguna jasa kereta api. Metode yang digunakan peneliti adalah CSI (Customer Satisfaction Index) dan Service Quality, agent kantor Kereta Api Pusat Jakarta yang mengisi quesioner sebanyak 51 dari 80 dengan hasil 78,76\% pada CSI dan 0,24 pada servqual. Aplikasi pelayanan pelanggan ini berpengaruh positip terhadap kepuasan pelanggan, sekaligus evaluasi bagi penyedia aplikasi.
\end{abstract}

Kata Kunci: Aplikasi Pelayanan Pelanggan, Genesys, Kereta Api Indonesia, CSI dan ServQual.

\begin{abstract}
Kereta Api Indonesia (KAI) as one of the state-owned companies that provide services to the public feels good a few years back and is the aim of researchers to conduct a survey of customer satisfaction with one of the Microsoft product Genesys customer service applications that have been connected with social media as a supporting application in serving train service users. The method used by researchers is the CSI (Customer Satisfaction Index) and Service Quality, the Jakarta Central Railway office agent who filled in the questionnaires as much as 51 of 80 with $78.76 \%$ results in CSI and 0.24 on servqual. This customer service application has a positive effect on customer satisfaction, as well as an evaluation for application providers.
\end{abstract}

Keyword: Customer Service Application, Genesys, Indonesian Railways, CSI and ServQual.

\section{PENDAHULUAN}

Beragam kemajuan teknologi smart card pada dunia transportasi publik [1] "Tidak hanya pemerintah tidak selalu memuaskan seperti yang diyakini banyak orang, tetapi ia dapat dan telah meningkat (atau setidaknya beberapa komponennya telah membaik) dalam bagaimana ia berinteraksi dengan dan dalam apa yang ditawarkan ke warga negara dari waktu ke waktu." [2]. Transportasi publik yang bergerak dibidang jasa, khususnya pada tahapan layanan purna jual peran customer service sangat penting dalam menangani setiap keluhan yang ada dari perilaku pelanggan yang mungkin timbul [3].
Dengan adanya customer service yang memiliki kemampuan komunikasi yang baik, pelanggan akan memiliki tempat untuk menyampaikan pengaduannya dan tentunya akan sedikit mengurangi rasa kecewa yang mungkin timbul akibat dari transaksi yang telah terjadi sebagi pengguna jasa. Komunikasi yang tepat dapat merubah rasa kecewa yang timbul tersebut menjadi satu kepuasan bagi pengguna jasa sehingga mereka dapat tetap memutuskan untuk menggunakan jasa pelayanan kita, inilah yang disebut memenangkan pengguna jasa. 
Customer Service di PT. KAI berfungsi sebagai tempat para pengguna jasa kereta api mendapatkan informasi, menyampaikan keluhan, menyampaikan saran, dan memesan tiket. Oleh karena itu mengingat hal ini sangat penting bagi suatu pelayanan di PT. KAI untuk memuaskan pengguna jasa. Kepuasan memiliki hubungan yang selaras dengan kinerja dan harapan. Seseorang akan merasa puas jika harapan atas kinerja, sama dengan atau melebihi dari kinerja yang benar-benar terjadi, dan sebaliknya. Konsep kepuasan pelanggan memiliki pengertian tingkat kepuasan seseorang pelanggan atau pemakai jasa setelah membandingkan kenyataan dari kinerja atau hasil yang dirasakan dengan harapan dan persepsinya terhadap jasa tersebut [4].

Kepuasan pelanggan tidak selalu disertai loyalitas terhadap transportasi berbasis rel ini [5] akan tetapi berbagai inovasi yang dikeluarkan oleh PT. KAI boleh dikatakan penting untuk merespon segala kendala dalam pelayanan transportasi kepada publik [6]. Penulis meneliti aplikasi pelayanan pelanggan agar mendapat perspektif imbang antara penyedia jasa transportasi dalam hal ini PT. KAI dan korporasi dibalik aplikasi pelayanan pelanggan dalam menjawab perkembangan teknologi yang terkini dan dapat memudahkan pelanggan kereta serta kerja sama yang berkelanjutan.

Penelitian ini sendiri dilakukan langsung ke masing-masing petugas customer service yang ada di PT. KAI untuk mengetahui bagaimana mereka melayani setiap pelanggan yang menghubungi mereka, hal apa saja yang biasanya mereka dapat dari pelanggan, dan untuk mengetahui respon dari tiap petugas customer service dalam menghadapi setiap pelanggan yang menghubungi mereka. Melalui Genesys, aplikasi call centre, yang dikembangkan oleh rekan kerja PT.KAI dimana aplikasi ini telah terhubung dengan media sosial seperti Facebook dan Twitter.

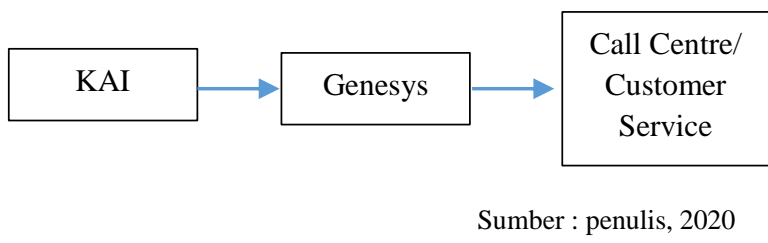

\section{Gambar 1. Flow Genesys di Contact Center Customer Service Inbound}

\section{METODE PENELITIAN}

Penelitian kualitative ini dilakukan dengan menggunakan metode Customer Satisfaction Index (CSI) berfungi untuk mengukur tingkat kepuasan secara menyeluruh dengan melihat tingkat kepentingan dari atribut- atribut jasa. Untuk menjadikan pelanggan sebagai pusat dengan mengetahui hak dan keinginan sehingga tercapai tujuan yang sama, pada akhirnya didapatilah pelanggan setia [7].

Untuk mengetahui besarnya CSI, maka dapat dilakukan langkah - langkah sebagai berikut [8]:

- Menentukan tingkat harapan / mean importance score (MIS).

- Menentukan nilai rata-rata tingkat kenyataan yang dirasakan pelanggan / pengguna jasa tiap variabel atau pernyataan / Mean Satisfaction Score (MSS).

- Membuat bobot nilai MIS per atribut terhadap total MIS seluruh atribut / Weight Factor (WF).

- Membuat Weight Score (WS) Bobot ini merupakan perkalian antara WF dengan rata-rata tingkat kenyataan pelayanan yang dirasakan sebagai MSS (Mean Satisfaction Score).

Sampel yang di tes sebesar 51 dari 80 populasi pegawai customer service PT.KAI, dengan 22 pernyataan. Skor CSI untuk tiap pernyataan bagi masing-masing 
pegawai dapat dihitung berdasarkan rumus berikut:

$$
C S I=\frac{T}{5 Y} \times 100 \%
$$

Dimana

$\mathrm{T}$ : total skor harapan dan kualitas dari tiap atribut

5 : nilai maksimum pada skala pengukuran likert

$\mathrm{Y}$ : nilai total rata-rata harapan

Tabel 1. Kriteria Tingkat Kepuasan

\begin{tabular}{ccc}
\hline No & Nilai CSI \% & Keterangan \\
\hline 1 & $81 \%-100 \%$ & Sangat Puas \\
2 & $66 \%-80 \%$ & Puas \\
3 & $51 \%-65 \%$ & $\begin{array}{c}\text { Cukup Puas } \\
\text { Kurang Puas }\end{array}$ \\
4 & $35 \%-50 \%$ & Tidak Puas \\
\hline 5 & $0 \%-34 \%$ & Sumber : [6]
\end{tabular}

Bila nilai yang didapat diatas 50\%, maka dapat dikatakan bahwa pengguna jasa sudah merasa puas sebaliknya bila nilai CSI di bawah $50 \%$ pengguna jasa belum dikatakan puas.

Metode Service Quality digunakan untuk mengetahui dan menilai kualitas service atau jasa yang diberikan oleh pihak yang memberikan jasa dalam hal ini PT.KAI kepada publik yang menggunakannya [9][10].

Rumus yang digunakan adalah :

$\mathrm{Q}=\mathrm{P}-\mathrm{E}$

Dimana:

$\mathrm{Q}=$ Kualitas Pelayanan Pelanggan

$\mathrm{E}=$ Harapan Pelanggan atas Kualitas

Pelayanan

$\mathrm{P}=$ Pelayanan yang sesungguhnya diterima

\section{HASIL DAN PEMBAHASAN}

Berdasarkan langkah-langkah diatas, maka dapat dihitung nilai Customer Satisfaction Index (CSI) tiap variabel dari tiap pernyataan untuk mengetahui tingkat kepuasan aplikasi.

Berikut rangkuman hasil olah data kuesioner pada tabel 2.

Tabel 2. Hasil olah data CSI

\begin{tabular}{|c|c|c|c|c|}
\hline No & Pernyataan & $\begin{array}{l}\text { Hara } \\
\text { pan } \\
\text { (I) } \\
\end{array}$ & $\begin{array}{l}\text { Kua } \\
\text { litas } \\
(\mathbf{P}) \\
\end{array}$ & $\begin{array}{l}\text { Skor } \\
\text { (S) }\end{array}$ \\
\hline \multicolumn{5}{|c|}{ Dimensi Akses dan Keamanan } \\
\hline 1 & $\begin{array}{l}\text { Aplikasi ini mudah di } \\
\text { akses dan di navigasi. }\end{array}$ & 4.28 & 4.04 & 17.27 \\
\hline 2 & $\begin{array}{l}\text { Aplikasi ini selalu } \\
\text { ada, selalu tersedia, } \\
\text { dan mudah } \\
\text { ditemukan. }\end{array}$ & 3.96 & 5.00 & 17.09 \\
\hline 3 & $\begin{array}{l}\text { Aplikasi ini memiliki } \\
\text { keamanan yang } \\
\text { memadai untuk } \\
\text { melakukan transaksi }\end{array}$ & 4.10 & 3.82 & 15.67 \\
\hline \multicolumn{5}{|c|}{ Dimensi Fasilitas Penunjang Memadai } \\
\hline 4 & $\begin{array}{l}\text { Aplikasi ini memiliki } \\
\text { fasilitas pencarian } \\
\text { kontak yang memadai }\end{array}$ & 4.31 & 3.94 & 17.00 \\
\hline 5 & $\begin{array}{l}\text { Aplikasi ini memiliki } \\
\text { tautan (links) yang } \\
\text { valid dan beragam. }\end{array}$ & 3.82 & 4.14 & 15.82 \\
\hline 6 & $\begin{array}{l}\text { Aplikasi ini dapat } \\
\text { dipersonalisasi sesuai } \\
\text { dengan keinginan } \\
\text { pengguna }\end{array}$ & 3.90 & 3.57 & 13.93 \\
\hline 7 & $\begin{array}{l}\text { Aplikasi ini memiliki } \\
\text { kecepatan yang } \\
\text { memadai ketika } \\
\text { dibuka }\end{array}$ & 3.53 & 4.22 & 14.88 \\
\hline 8 & $\begin{array}{l}\text { Aplikasi ini memiliki } \\
\text { fitur interaktif yang } \\
\text { banyak dan beragam }\end{array}$ & 3.98 & 4.10 & 16.31 \\
\hline 9 & $\begin{array}{l}\text { Informasi yang } \\
\text { tersedia dalam } \\
\text { aplikasi sangat } \\
\text { berguna bagi saya }\end{array}$ & 4.08 & 3.88 & 15.83 \\
\hline 10 & $\begin{array}{l}\text { Informasi yang } \\
\text { tersedia dalam } \\
\text { aplikasi ini lengkap } \\
\text { atau komprehensif }\end{array}$ & 3.90 & 4.35 & 16.99 \\
\hline \multicolumn{5}{|c|}{ Dimensi Penunjang Kebutuhan Pelanggan } \\
\hline 11 & $\begin{array}{l}\text { Informasi yang } \\
\text { tersedia dalam } \\
\text { aplikasi ini disajikan } \\
\text { dengan jelas dan } \\
\text { mudah dipahami. }\end{array}$ & 4.28 & 3.86 & 16.51 \\
\hline 12 & $\begin{array}{l}\text { Informasi yang } \\
\text { tersedia dalam } \\
\text { aplikasi ini ringkas } \\
\text { namun padat. }\end{array}$ & 3.49 & 4.00 & 13.96 \\
\hline
\end{tabular}




\begin{tabular}{|c|c|c|c|c|}
\hline 13 & $\begin{array}{l}\text { Informasi yang } \\
\text { tersedia dalam } \\
\text { Aplikasi ini akurat } \\
\text { dan dapat dipercaya. }\end{array}$ & 4.41 & 3.86 & 17.04 \\
\hline \multicolumn{5}{|c|}{ Dimensi Desain } \\
\hline 14 & $\begin{array}{l}\text { Dalam aplikasi ini } \\
\text { tersedia sumber atau } \\
\text { kontak informasi yang } \\
\text { bisa dihubungi } \\
\text { (nomor telefon, } \\
\text { alamat email, dan } \\
\text { lain- lain). }\end{array}$ & 3.77 & 3.77 & 15.95 \\
\hline 15 & $\begin{array}{l}\text { Dalam aplikasi ini } \\
\text { tersedia informasi } \\
\text { yang bersifat umum } \\
\text { tentang organisasi } \\
\text { atau perusahaan } \\
\text { pemiliki aplikasi ini } \\
\text { (visi, misi, tujuan } \\
\text { organisasi, struktur } \\
\text { organisasi, dan lain- } \\
\text { lain) }\end{array}$ & 3.90 & 3.71 & 14.46 \\
\hline 16 & $\begin{array}{l}\text { Dalam aplikasi ini } \\
\text { tersedia informasi } \\
\text { tentang hak dan } \\
\text { kewajiban pengguna }\end{array}$ & 3.90 & 3.57 & 13.93 \\
\hline 17 & $\begin{array}{l}\text { Dalam Aplikasi ini } \\
\text { tersedia informasi } \\
\text { tentang layanan yang } \\
\text { dapat dimanfaatkan } \\
\text { pelanggan/pengguna. }\end{array}$ & 3.67 & 3.41 & 12.51 \\
\hline 18 & $\begin{array}{lr}\text { Tampilan } & \text { aplikasi ini } \\
\text { tampak } & \text { menarik } \\
\text { (atraktif). } & \\
\end{array}$ & 4.20 & 3.69 & 15.47 \\
\hline 19 & $\begin{array}{l}\text { Tampilan aplikasi ini } \\
\text { tertata dengan rapi }\end{array}$ & 4.18 & 3.98 & 16.62 \\
\hline 20 & $\begin{array}{l}\text { Aplikasi ini } \\
\text { menggunakan ukuran } \\
\text { font yang } \\
\text { proporsional }\end{array}$ & 4.53 & 4.02 & 18.21 \\
\hline 21 & $\begin{array}{l}\text { Aplikasi ini } \\
\text { menggunakan } \\
\text { tatawarna yang serasi }\end{array}$ & 4.14 & 3.94 & 16.31 \\
\hline 22 & $\begin{array}{l}\text { Aplikasi ini } \\
\text { menggunakan fasilitas } \\
\text { multimedia dengan } \\
\text { tepat dan proporsional }\end{array}$ & 4.39 & 4.02 & 17.66 \\
\hline \multicolumn{2}{|c|}{ Total } & $\begin{array}{l}88.72 \\
(\mathrm{Y})\end{array}$ & & $\begin{array}{l}349.39 \\
(\mathrm{~T})\end{array}$ \\
\hline
\end{tabular}

Dari tabel 1 dapat dilihat semua nilai kolom harapan (I) dan kualitas (P) pada tiap pernyataan sudah didapatkan. Selanjutnya menentukan nilai skor (T) pada tiap pernyataan dengan cara mengkalikan nilai I dan nilai $\mathrm{P}$ pada tiap pernyataan. Langkah selanjutnya untuk mendapatkan nilai yang akan digunakan pada perhitungan CSI ada menjumlahkan total nilai I (Y) dan nilai total $\mathrm{S}$ (T) sehingga didapatkan nilai $\mathrm{Y}=88.72$ dan nilai $\mathrm{T}=349.39$.

Selanjutnya nilai Y dan nilai T dimasukkan ke dalam rumus CSI untuk mendapatkan nilai CSI pada penelitian ini, berikut ini adalah perhitungan rumus CSI :

$\mathrm{CSI}=\frac{349.39}{5 \times 88,72} \times 100 \%=78.76 \%$

Tahap berikutnya adalah servqual untuk menentukan tingkat kualitas aplikasi Genesys yang dinilai oleh pihak Customer Service PT. KAI. Data yang sudah didapatkan diolah dengan menggunakan metode Service Quality pada tabel 3.

Tabel 3. Hasil olah data ServQual

\begin{tabular}{|c|c|c|c|c|}
\hline $\begin{array}{l}\mathrm{N} \\
\mathrm{o}\end{array}$ & Pernyataan & $\begin{array}{l}\text { Harap } \\
\text { an (E) }\end{array}$ & $\begin{array}{l}\text { Kual } \\
\text { itas } \\
(\mathrm{P}) \\
\end{array}$ & $\begin{array}{l}\text { Skor } \\
\text { (Q) }\end{array}$ \\
\hline \multicolumn{5}{|c|}{ Dimensi Akses dan Keamanan } \\
\hline 1 & $\begin{array}{l}\text { Aplikasi ini mudah di } \\
\text { akses dan di navigasi. }\end{array}$ & 4.04 & 4.27 & 0.23 \\
\hline 2 & $\begin{array}{l}\text { Aplikasi ini selalu ada, } \\
\text { selalu tersedia, dan } \\
\text { mudah ditemukan. }\end{array}$ & 3.96 & 5.00 & 1.04 \\
\hline 3 & $\begin{array}{l}\text { Aplikasi ini memiliki } \\
\text { keamanan yang } \\
\text { memadai untuk } \\
\text { melakukan transaksi }\end{array}$ & 4.10 & 3.82 & 0.28 \\
\hline \multicolumn{5}{|c|}{ Dimensi Fasilitas Penunjang Memadai } \\
\hline 4 & $\begin{array}{l}\text { Aplikasi ini memiliki } \\
\text { fasilitas pencarian } \\
\text { kontak yang memadai }\end{array}$ & 4.31 & 3.94 & -0.37 \\
\hline 5 & $\begin{array}{l}\text { Aplikasi ini memiliki } \\
\text { tautan (links) yang valid } \\
\text { dan beragam. }\end{array}$ & 3.82 & 4.14 & 0.32 \\
\hline 6 & $\begin{array}{l}\text { Aplikasi ini dapat } \\
\text { dipersonalisasi sesuai } \\
\text { dengan keinginan } \\
\text { pengguna }\end{array}$ & 3.90 & 3.57 & -0.33 \\
\hline \multicolumn{5}{|c|}{ Dimensi Kualitas Informasi } \\
\hline 7 & $\begin{array}{l}\text { Aplikasi ini memiliki } \\
\text { kecepatan yang } \\
\text { memadai ketika dibuka }\end{array}$ & 3.53 & 4.22 & 0.69 \\
\hline 8 & $\begin{array}{l}\text { Aplikasi ini memiliki } \\
\text { fitur interaktif yang } \\
\text { banyak dan beragam }\end{array}$ & 3.98 & 4.10 & 0.12 \\
\hline 9 & $\begin{array}{l}\text { Informasi yang tersedia } \\
\text { dalam aplikasi sangat } \\
\text { berguna bagi saya }\end{array}$ & 4.08 & 3.88 & -0.2 \\
\hline 10 & $\begin{array}{l}\text { Informasi yang tersedia } \\
\text { dalam aplikasi ini } \\
\text { lengkap atau } \\
\text { komprehensif }\end{array}$ & 3.90 & 4.35 & 0.45 \\
\hline
\end{tabular}




\begin{tabular}{|c|c|c|c|c|}
\hline \multicolumn{5}{|c|}{ Dimensi Penunjang Kebutuhan Pelanggan } \\
\hline 11 & $\begin{array}{l}\text { Informasi yang tersedia } \\
\text { dalam aplikasi ini } \\
\text { disajikan dengan jelas } \\
\text { dan mudah dipahami. }\end{array}$ & 4.28 & 3.86 & -0.42 \\
\hline 12 & $\begin{array}{l}\text { Informasi yang tersedia } \\
\text { dalam aplikasi ini } \\
\text { ringkas namun padat. }\end{array}$ & 3.49 & 4.00 & 0.51 \\
\hline 13 & $\begin{array}{l}\text { Informasi yang tersedia } \\
\text { dalam Aplikasi ini } \\
\text { akurat dan dapat } \\
\text { dipercaya. }\end{array}$ & 4.41 & 3.86 & -0.55 \\
\hline \multicolumn{5}{|c|}{ Dimensi Desain } \\
\hline 14 & $\begin{array}{l}\text { Dalam aplikasi ini } \\
\text { tersedia sumber atau } \\
\text { kontak informasi yang } \\
\text { bisa dihubungi (nomor } \\
\text { telefon, alamat email, } \\
\text { dan lain- lain). }\end{array}$ & 3.24 & 3.76 & 0.52 \\
\hline 15 & $\begin{array}{l}\text { Dalam aplikasi ini } \\
\text { tersedia informasi yang } \\
\text { bersifat umum tentang } \\
\text { organisasi atau } \\
\text { perusahaan pemiliki } \\
\text { aplikasi ini (visi, misi, } \\
\text { tujuan organisasi, } \\
\text { struktur organisasi, dan } \\
\text { lain-lain) }\end{array}$ & 3.90 & 3.71 & -0.19 \\
\hline 16 & $\begin{array}{l}\text { Dalam aplikasi ini } \\
\text { tersedia informasi } \\
\text { tentang hak dan } \\
\text { kewajiban pengguna }\end{array}$ & 3.90 & 3.57 & -0.33 \\
\hline 17 & $\begin{array}{l}\text { Dalam Aplikasi ini } \\
\text { tersedia informasi } \\
\text { tentang layanan yang } \\
\text { dapat dimanfaatkan } \\
\text { pelanggan/pengguna. }\end{array}$ & 3.67 & 3.41 & -0.26 \\
\hline 18 & $\begin{array}{l}\text { Tampilan aplikasi ini } \\
\text { tampak menarik } \\
\text { (atraktif). }\end{array}$ & 4.20 & 3.69 & -0.51 \\
\hline 19 & $\begin{array}{l}\text { Tampilan aplikasi ini } \\
\text { tertata dengan rapi }\end{array}$ & 4.18 & 3.98 & -0.2 \\
\hline 20 & $\begin{array}{l}\text { Aplikasi ini } \\
\text { menggunakan ukuran } \\
\text { font yang proporsional }\end{array}$ & 4.53 & 4.02 & -0.51 \\
\hline 21 & $\begin{array}{l}\text { Aplikasi ini } \\
\text { menggunakan tatawarna } \\
\text { yang serasi }\end{array}$ & 4.14 & 3.94 & -0.2 \\
\hline 22 & $\begin{array}{l}\text { Aplikasi ini } \\
\text { menggunakan fasilitas } \\
\text { multimedia dengan } \\
\text { tepat dan proporsional }\end{array}$ & 4.39 & 4.02 & -0.37 \\
\hline \multicolumn{2}{|c|}{ Total rata-rata } & 4.04 & 4.28 & \\
\hline
\end{tabular}

Dari tabel 3 terdapat hasil 4.04 yang didapat dari total skor 206 pada kolom harapan dibagi 51 jumlah dari responden. Dan angka 4.28 didapatkan dari total skor 218 pada kolom kualitas (P) dibagi 51 jumlah responden. Perhitungan yang sama digunakan untuk mendapatkan nilai harapan dan kualitas pada tiap-tiap pernyataan berikutnya. Selanjutanya nilai $\mathrm{P}$ dikurangi dengan nilai $\mathrm{E}$ untuk menghasilkan nilai $\mathrm{Q}$ dan perhitungan inipun digunakan pada setiap pernyataan yang ada.

Service Quality $=4.28-4.04=0.24$

\section{SIMPULAN}

Secara keseluruhan tingkat kepuasan Customer Service PT. KAI terhadap aplikasi Genesys dengan menggunakan metode perhitungan Customer Satisfaction Index (CSI) sebesar 78.76\%, yang dapat di artikan bahwa Customer Service PT. KAI merasa puas menggunakan aplikasi Genesys. Ukuran font, gap dan tampilan atraktif menjadi evaluasi perbaikan bagi pengelola agar PT. KAI lebih maksimal dalam memberikan pelayanan dengan nilai negatif sebesar 13 dari 22 pernyataan.yang di uji.

Untuk meningkatkan pelayanan Customer Service PT.KAI, disarankan menggunakan atau menerapkan fitur efektifitas pekerja dalam merespon tiap masukkan atau keluhan sehingga tercipta nuasa kerja yang profesional, selain memperbaiki aplikasi Genesys hasil dari penelitian ini.

\section{DAFTAR PUSTAKA}

[1] F. Kurauchi, Public Transport Planning with Smart Card Data. CRC Press, 2017.

[2] F. V. Morgeson, Citizen Satisfaction. Palgrave Macmillan, 2014.

[3] I. G. Mahatma and Y. Bakti, Public Transport Passengers' Behavioural Intentions_ Paratransit in Jabodetabek-Indonesia. Springer International Publishing, 2014.

[4] V. R. Bolang, J. D. . Massie, and A. S. Soegoto, "Peran Pelayanan Teller 
dan Costumer Service Terhadap Kepuasan Pelanggan Pada Bank BRI Unit Karombasan Cabang Manado," J. EMBA, vol. 3, no. 3, pp. 1126-1139, 2015.

[5] Hatane Semuel and Nadya Wijaya, "Service Quality, Perceive Value, Satisfaction, Trust, Dan Loyalty Pada Pt. Kereta Api Indonesia Menurut Penilaian Pelanggan Surabaya," J. Manaj. Pemasar., vol. 4, no. 1, pp. 23-37, 2009.

[6] G. Anggadwita, "Service Innovation in Public Sector: A Case Study on PT. Kereta Api Indonesia," J. Soc. Dev. Sci., vol. 4, no. 7, pp. 308-315, 2013.

[7] B. Liu, "Customer satisfaction index model building and empirical research of sports fitness and entertainment industry," Int. Conf. Manag. Serv. Sci. MASS 2011, 2011.

[8] Tjiptono, Fandy. Service Management. Andi Offset. Yogyakarta 2012.

[9] A. Yildirim, S. Ozcan, and K. E. Yildirim, "Integrated Usage of the SERVQUAL and Quality Function Deployment Techniques in the Assessment of Public Service Quality: The Case of Ardahan Municipality," Bus. Econ. Res. J., vol. 10, no. 4, pp. 885-901, 2019.

[10] Z. Shi and H. Shang, "A Review on Quality of Service and SERVQUAL Model," in HCI in Business, Government and Organizations, 2020, pp. 188-204. 